Koushik GHOSH${ }^{1}$, Sukanta Kumar $S E N^{2}$, Arun Kumar $R A Y^{1}$

Aquaculture

\title{
GROWTH AND SURVIVAL OF ROHU, LABEO ROHITA (HAMILTON) SPAWN FED DIETS SUPPLEMENTED WITH FISH INTESTINAL MICROFLORA
}

\section{WZROST I PRZEŻYWALNOŚĆ WYLĘGU GRUBOWARGA, LABEO ROHITA (HAMILTON) ŻYWIONEGO PASZAMI WZBOGACONYMI MIKROFLORĄ JELITOWĄ RYB}

\author{
${ }^{1}$ Fisheries Laboratory, Department of Zoology, Visva-Bharati University, Santiniketan, \\ West Bengal, India \\ ${ }^{2}$ Microbiology Laboratory, Department of Botany, Visva-Bharati University, Santiniketan, \\ West Bengal, India
}

A 21-day feeding experiment was conducted to assess the effects of diets supplemented with fish intestinal bacteria producing extracellular enzyme on growth and survival of rohu, Labeo rohita (Hamilton) spawn (average weight $0.3 \mathrm{mg}$ ). Intestinal bacteria were isolated from healthy rohu fingerlings (average weight $3.51 \pm 0.31 \mathrm{~g}$ ). Six isocaloric $\left(4.24 \mathrm{kcal} \cdot \mathrm{g}^{-1}\right)$ and isonitrogenous (approximately $35 \%$ crude protein) diets (D1-D6) were prepared containing 32\% fish meal, $34 \%$ mustard oil cake, $30 \%$ rice bran, $2 \%$ cod liver oil, and $2 \%$ vitamin premix. Experimental diets (D2-D6) were supplemented with the isolated bacterial strain Bacillus circulans $\operatorname{Lr} 1.1$ at five different levels $\left(4 \times 10^{5}, 4 \times 10^{6}, 4 \times 10^{7}\right.$, $4 \times 10^{8}$ and $4 \times 10^{10}$ cells per $100 \mathrm{~g}$ of feed, respectively). Rearing of spawn on diet D5 (supplemented with $4 \times 10^{8}$ cells per $100 \mathrm{~g}$ ) resulted in better growth and survival (97.33 $\pm 1.15 \%)$ of rohu spawn compared to those with the control diet (diet D1, without any microflora supplementation) and other experimental diets. Diet D5 resulted in significantly higher growth and specific growth rate (SGR) followed by diets D6 and D4. RNA and DNA contents in the spawn were measured as an index of growth. The correlation coefficient ( $r$ value) of 0.831 and regression line having a slope of 0.79 suggested a significant positive correlation $(0.01$ level) between RNA-DNA ratio and specific growth rate. 


\section{INTRODUCTION}

The degree of survival and well being of carp larvae dictate the success and failure of the fish culture programme. Due to non-availability of proper larval diet, the rate of survival is, in general, very low. Therefore, supplemental nutrition in the form of artificial compounded feed in appropriate quality and quantity is one of the important factors and development of larval diet should be given priority. The importance of a quality larval diet has been increasing day by day with the advancement of multiple spawning of carps. Several attempts have been made to develop artificial diets to replace live food in the rearing of fish larvae (Chow 1980; Bryant and Matty 1981; Anonymous 1983; Dabrowski and Kaushik 1985; Csengeri and Petitjean 1987; Alami-Durante et al. 1991; Mohanty et al. 1996). Although there are reports on the use of microencapsulated diets (Chow 1980; Anonymous 1983), no standard larval diets are available for Indian major carps.

"Probiotics are the live microbial cells that beneficially affect the host animal with the aim of improving health" (Gatesoupe 1999). In the present study, an attempt has been made to investigate the probiotic effects of extracellular enzyme producing microflora isolated from fish gut, on the growth and survival of rohu, Labeo rohita, spawn. RNA-DNA ratio was measured after rearing period as an index of growth.

\section{MATERIAL AND METHODS}

\section{Isolation and selection of intestinal bacterial flora}

Intestinal bacterial flora was isolated from ten healthy fingerlings of rohu, Labeo rohita (average weight $3.51 \pm 0.31 \mathrm{~g}$ ). The fish were starved for $24 \mathrm{~h}$ and the ventral surface of the fish was scrubbed with $1 \%$ iodine solution (Trust and Sparrow 1974). The intestine from all fish was dissected out aseptically and homogenised with $0.89 \% \mathrm{NaCl}$ solution (10:1) (Das and Tripathi 1991) The homogenate was used as inoculum. One $\mathrm{ml}$ of homogenised sample $\left(10^{-1}\right)$ was spread on sterilised soybean-casein digest agar (Tryptone Soya Agar, HiMedia, India) plates and incubated at $37^{\circ} \mathrm{C}$ for $24 \mathrm{~h}$ in duplicate. Colonies with different morphological appearance were isolated and streaked separately on TSA plates to check their purity. Isolated colonies were characterised and identified (Ghosh et al. 2002). Among them Lr 1.1 strain of Bacillus circulans was selected for incorporation into diets for its excellent protease and moderate cellulase producing capacities.

\section{Diet preparation}

Six isocaloric and isonitrogenous diets (D1-D6) were prepared containing similar ingredient composition (fish meal, 32\%; mustard oil cake, 34\%; rice bran, 30\%; cod liver oil, $2 \%$; vitamin premix, 2\%). Experimental diets (D2-D6) were supplemented with the isolated bacterial strain of Bacillus circulans at five different levels $\left(4 \times 10^{5}, 4 \times 10^{6}, 4 \times 10^{7}\right.$, 
$4 \times 10^{8}$, and $4 \times 10^{10}$ cells per $100 \mathrm{~g}$ of feed, respectively. The control diet (D1) was not supplemented with bacterial cells (Table 1). The feed ingredients were finely powdered and fortified with cod liver oil and vitamin mineral premix (Vitaminetes Forte, Roche India Ltd., India). The experimental diets were mixed with desired quantities of bacterial cells in tryptone soya broth suspension culture. The homogenous mixtures of different diets were spread over aluminium foil and dried at $40^{\circ} \mathrm{C}$ in a hot air oven. The dried mixture was powdered and sieved to obtain micropellets.

Table 1

Ingredient composition (\% dry weight) and proximate composition (on dry matter basis) of experimental diets

\begin{tabular}{|c|c|c|c|c|c|c|}
\hline \multirow{2}{*}{ Ingredients } & \multicolumn{6}{|c|}{ Diets } \\
\hline & D1 & $\mathrm{D} 2$ & D3 & $\mathrm{D} 4$ & D5 & $\overline{\text { D6 }}$ \\
\hline Fish meal & 32 & 32 & 32 & 32 & 32 & 32 \\
\hline Mustard oil cake & 34 & 34 & 34 & 34 & 34 & 34 \\
\hline Rice bran & 30 & 30 & 30 & 30 & 30 & 30 \\
\hline Cod liver oil & 2 & 2 & 2 & 2 & 2 & 2 \\
\hline Vitamin mineral mixture ${ }^{a}$ & 2 & 2 & 2 & 2 & 2 & 2 \\
\hline No. of Bacillus circulans cells (per $100 \mathrm{~g}$ ) & 0 & $4 \times 10^{5}$ & $4 \times 10^{6}$ & $4 \times 10^{7}$ & $4 \times 10^{8}$ & $4 \times 10^{10}$ \\
\hline \multicolumn{7}{|c|}{ Proximate composition(\%) ${ }^{b}$} \\
\hline Moisture & 5.29 & 5.64 & 5.87 & 6.12 & 5.95 & 6.23 \\
\hline Dry matter & 94.71 & 94.36 & 94.13 & 93.88 & 94.05 & 93.77 \\
\hline Crude protein & 34.86 & 34.65 & 35.33 & 34.66 & 35.83 & 36.12 \\
\hline Crude lipid & 7.06 & 7.28 & 7.07 & 7.32 & 7.52 & 7.28 \\
\hline Ash & 13.49 & 13.42 & 13.67 & 13.17 & 13.71 & 13.80 \\
\hline Crude fibre & 10.63 & 10.60 & 10.58 & 10.55 & 10.52 & 10.71 \\
\hline Nitrogen free extract (NFE) & 28.67 & 28.41 & 27.48 & 28.18 & 26.47 & 25.87 \\
\hline Organic matter & 81.22 & 80.94 & 80.46 & 80.71 & 80.34 & 79.97 \\
\hline Gross energy $\left(\mathrm{kcal} \cdot \mathrm{g}^{-1}\right)$ & 4.25 & 4.25 & 4.22 & 4.24 & 4.25 & 4.23 \\
\hline
\end{tabular}

${ }^{\mathrm{a}}$ Vitamin and mineral mixture (Vitaminetes Forte, Roche Products Ltd, 24128 Pt. M. M. Malaviya Road, Mumbai 400 034, India).

${ }^{\mathrm{b}}$ Number of samples for each determination $=3$.

\section{Experimental design}

The experiment was conducted in laboratory condition for 21 days. Rohu spawn were obtained from induced spawning of a single pair of rohu supplied by a local fish seed dealer. Four-day-old larvae were brought to the laboratory and acclimated for two days feeding on mixed plankton. One hundred acclimated spawn of similar size (average length $5 \mathrm{~mm}$; weight $0.30 \mathrm{mg}$ ) were randomly distributed in plastic containers filled with $15 \mathrm{dm}^{3}$ of unchlorinated water from a deep tubewell. Constant aeration was provided to each container using air compressor. Dissolved oxygen content, temperature, and $\mathrm{pH}$ of water were: $4.9-7.3 \mathrm{mg} \cdot \mathrm{dm}^{-3}, 22.8-28.2^{\circ} \mathrm{C}$ and $6.6-7.3$ respectively during the experimental period. 
Feeds were offered ad libitum every 30 minutes commencing at $0900 \mathrm{hrs}$ daily. The unconsumed feed and faecal matter were removed twice a day by siphoning. The containers were thoroughly cleaned every other day and filled with fresh water.

Chemical analyses and data collection

Proximate composition of the diets was analysed according to the AOAC procedures (Helrich 1990). Growth increment was monitored regularly at 5 day intervals by sampling 20 larvae from each container. Final sampling was done after 20 days by weighing all the surviving fish from container after ensuring complete evacuation of feed by the starving process.

Average live weight gain (\%) and specific growth rate (SGR) were calculated using standard methods outlined by Steffens (1989).

To estimate DNA and RNA contents, DNA and RNA aliquots were prepared from $100 \mathrm{mg}$ of fish tissue (Munro and Fleck 1966). DNA and RNA contents of the aliquot were estimated following the methods of Burton (1956) and Marham (1955), respectively. The ratio of RNA to DNA was used as an index to growth.

The water quality parameters were monitored following the methods outlined by APHA (Anonymous 1985).

ANOVA, followed by multiple range test (Duncan 1955), was employed for statistical analysis. To correlate RNA-DNA ratio and specific growth rate, correlation coefficient ( $r$ value) and regression analysis between these two parameters were performed using Microsoft Excel software.

\section{RESULTS}

The ingredient composition and proximate composition of the formulated diets are presented in the Table 1. Diets were isonitrogenous (about $35 \%$ crude protein) and isocaloric $\left(4.24 \pm 1 \mathrm{kcal} \cdot \mathrm{g}^{-1}\right)$. Dry matter, lipid, and ash contents varied within a close range (93.77-94.71\%, 7.06-7.32\% and $13.17-13.80 \%$, respectively).

No disease or abnormality of rohu spawn was observed during the experimental period. The performance of spawn in terms of growth, survival and RNA-DNA contents is depicted in Table 2. Bacillus circulans Lr 1.1 incorporated diet D5 resulted in best growth and survival of rohu spawn comparing to the control diet (D1) and other experimental diets. Diet D5 resulted in significantly higher $(P>0.05)$ growth and specific growth rate (SGR) followed by diets D6 and D4. Higher growth was supported by the increment of both, weight and length of the spawn. Poor survivability of spawn was recorded with the control diet (without bacteria supplementation). However, it was improved with the supplementation of intestinal bacteria up to an inclusion level of $4 \times 10^{8}$ cells $100 \mathrm{~g}^{-1}$ of feed (D5). 
Table 2

Performance of rohu spawn fed experimental diets for 20 days.

The results are mean \pm SD of 5 determination

\begin{tabular}{|c|c|c|c|c|c|c|}
\hline \multirow{2}{*}{ Performance } & \multicolumn{6}{|c|}{ Diets } \\
\hline & D1 & $\overline{\mathrm{D} 2}$ & D3 & D4 & $\overline{\mathrm{D} 5}$ & $\overline{\mathrm{D} 6}$ \\
\hline Weight $(\mathrm{mg})^{\mathrm{a}}$ & $3.2 \pm 0.1^{d}$ & $6.4 \pm 0.23^{c}$ & $8.5 \pm 0.31^{b}$ & $8.9 \pm 0.25^{b}$ & $10.9 \pm 0.34^{\mathrm{a}}$ & $9.2 \pm 0.28^{\mathrm{ab}}$ \\
\hline Leng & $8.5 \pm 0.25^{\mathrm{d}}$ & $9.75 \pm 0.35^{\mathrm{c}}$ & $10.5 \pm 0.35^{\mathrm{b}}$ & $10.8 \pm 0.4^{b}$ & $12.8 \pm 0.50^{\mathrm{a}}$ & $11.0 \pm 0.25^{b}$ \\
\hline Surv & $81.66 \pm 2.08$ & $87.66 \pm 2.51^{b c}$ & $91.33 \pm 2.52^{b}$ & $94.66 \pm 1.52^{\mathrm{ab}}$ & $97.33 \pm 1.15^{\mathrm{a}}$ & $87.00 \pm 2.64^{c}$ \\
\hline SGR $\left(\% \cdot\right.$ day $\left.^{-1}\right)$ & $11.27 \pm 0.35^{\circ}$ & $14.57 \pm 0.43^{c}$ & $15.92 \pm 0.71^{b}$ & $16.14 \pm 0.75^{b}$ & $17.11 \pm 0.43^{\mathrm{a}}$ & $16.30 \pm 0.11^{\mathrm{at}_{3}}$ \\
\hline RNA (mg.g $\left.\mathrm{g}^{-1}\right)^{\mathrm{c}}$ & $0.67 \pm 0.02^{\mathrm{e}}$ & $1.14 \pm 0.03^{\mathrm{d}}$ & $1.15 \pm 0.03^{\mathrm{d}}$ & $1.28 \pm 0.02^{\mathrm{c}}$ & $1.92 \pm 0.04^{\mathrm{a}}$ & $1.73 \pm 0.03^{\mathrm{b}}$ \\
\hline DNA $\left(\mathrm{mg}^{\circ} \mathrm{g}^{-1}\right)^{\mathrm{d}}$ & $0.24 \pm 0.02^{\mathrm{a}}$ & $0.225 \pm 0.03$ & $0.225 \pm 0.01^{\circ}$ & $0.22 \pm 0.01^{\mathrm{c}}$ & $0.21 \pm 0.01^{\mathrm{a}}$ & $0.22 \pm 0.01^{\mathrm{a}}$ \\
\hline RNA/DNA & $2.79 \pm 0.13^{\mathrm{e}}$ & $5.07 \pm 0.21^{\mathrm{d}}$ & $5.11 \pm 0.25^{\mathrm{d}}$ & $5.82 \pm 0.29^{c}$ & $9.14 \pm 0.42^{\mathrm{a}}$ & $7.86 \pm 0.35^{\mathrm{b}}$ \\
\hline
\end{tabular}

${ }^{\mathrm{a}}$ Initial weight: $0.30 \mathrm{mg} ;{ }^{\mathrm{b}}$ Initial length: $5.0 \mathrm{~mm} ;{ }^{\mathrm{c}}$ Initial value of RNA: $0.32 \mathrm{mg} \cdot \mathrm{g}^{-1}$; ${ }^{\mathrm{d}}$ Initial value of DNA: $0.21 \mathrm{mg} \cdot \mathrm{g}^{-1}$

Values with same superscript in the same row are not significantly different $(P<0.05)$

The RNA and DNA contents of rohu spawn differed significantly $(P<0.05)$ among different dietary treatments. The group of spawn showing higher growth rate (with diet D5) exhibited higher RNA-DNA ratio. The elevated RNA-DNA ratio was associated with higher levels of RNA and lower levels of DNA.

A significant positive correlation was obtained between RNA-DNA ratio and specific growth rate of 18 dietary groups (6 groups in triplicate). The $r$-value of 0.831 suggests a significant relationship ( $99 \%$ significant) between growth and the RNA-DNA ratio (Fig. 1).

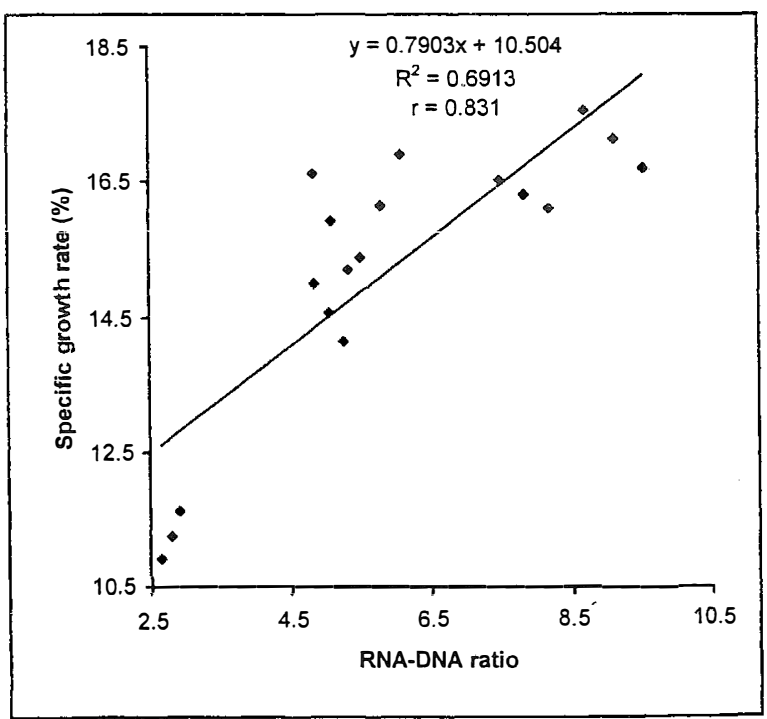

Fig. 1. A regression of the specific growth rate $v s$. RNA-DNA ratio of rohu spawn fed experimental diets for 21 days 
The regression analysis in which specific growth rate was correlated to its RNADNA ratio gave the regression line showing a slope of 0.7903 . The slope of the regression line was significant at the 0.01 level.

\section{DISCUSSION}

The development of fish farming on a commercial scale is limited for many species due to difficulties in producing sufficient quantities of larvae and juveniles, and high mortalities can occur during the early stages of larval rearing, especially during the transition from the yolk sac to the first feeding stage of development (Ringø and Birkbeck 1999). It is well known that in nurseries, rate of larval survival is very low $(30-40 \%)$ and hence use of the larval diet for large scale indoor rearing may be found economically justified in the long run without involving much management practices.

Rice bran and oil cakes of various origins are the most widely used ingredients in the preparation of conventional supplementary diets for carp larvae and fry. Mitra and Das (1965) studied the efficacy of oil cake, rice bran; and black gram as feed for carp larvae. Tripathi et al. (1979) obtained improved survival (over 80\%) of carp larvae using a diet comprising a mixture of fishmeal, groundnut oil cake, and rice bran (1:1:1). In those investigations basically fishmeal, rice bran, and mustard oil cake were used to formulate the diets. Csengeri and Petitjean (1987) reported a survival rate of $80 \%$ in cyprinid larvae using a liver based diet whereas, more than $80 \%$ survival rates were achieved in the present study even in the control groups.

The differences in growth and survival of rohu spawn between treatments could be attributed to the quality of diets. Supplementation of intestinal microflora increased the nutritional efficiency of the formulated diet. Fish fed diets D5 $\left(4 \times 10^{8}\right.$ cells $)$ and D6 $\left(4 \times 10^{10}\right.$ cells) resulted in better growth and survival of spawn in comparison to the control (without Bacillus supplementation) and other experimental diets. Improvement of the nutritional efficiency of diet may be due to the probiotic effect of the bacteria used. The importance of application of probiotics has been discussed by several authors (Gatesoupe 1991; Strøm and Ringø 1993; Mohanty et al. 1993, 1996; Swain et al. 1996). The main strategy of using probiotics is to isolate intestinal bacteria with favourable properties from mature animals and include them in the feed for immature animals of the same species (Gildberg et al. 1997). The beneficial effects of probiotics in larval rearing have been demonstrated in other fishes by several investigators (Charlon and Bergot 1984; Dabrowski and Kaushik 1985; Bergot et al. 1986; Alami-Durante et al. 1991).

The intestinal tract of fish larvae is much more simply organized and shorter than that of the adults (Stroband and Dabrowski 1979), which is associated a low production of digestive enzymes. The larvae therefore, simply do not have the necessary enzymes or the 
amount of digestive enzymes to digest the feed at the optimal level. Jancarik (1964) suggested that the fish larvae could utilize live food well because of the exogenous enzymes present within the food organisms taken in. Exogenous enzymes extracted from bacteria or fungi could therefore, be incorporated into larval feeds to aid in digestion. In the present study, Bacillus circulans bacteria producing extracellular enzyme, might have supplied digestive enzymes and certain essential nutrients to promote better growth and survival as indicated by Douillet and Langdon (1994), who observed faster growth and higher survival in Pacific oyster fed algae supplemented with CA2 bacterium.

RNA and DNA contents in the spawn were measured both prior to commencement and termination of the experiment, and the RNA-DNA ratio was correlated with the growth. The usefulness of RNA concentration as an indicator of growth has been proven by Neidhardt and Megasanik (1960) for bacteria and shown it to be equally applicable to fish. Rapidly growing organisms apparently synthesize and accumulate the RNA needed for protein synthesis. Consequently, RNA and the ratio of RNA to DNA are useful as an index of growth. In the present study, RNA-DNA ratios in rohu spawn were positively correlated to the trends in growth as has been indicated by several authors (Bulow 1970, 1971; Haines 1973, 1980; Bulow et al. 1981). Wilder and Stanley (1983) confirmed the relationship between growth and RNA-DNA ratios in brook trout, Salvelinus fontinalis and Atlantic salmon, Salmo salar. In the present study, the elevated RNA-DNA ratios were associated with higher levels of RNA and lower levels of DNA. Increased RNA-DNA ratios noticed in rohu spawn corresponding to growth increment are indicative of higher protein synthesis which could be attributed to probiotic effect of the bacterium used.

\section{CONCLUSIONS}

It is concluded from the results of this study that the supplementation of enzyme producing bacterial strain, Bacillus circulans Lr 1.1 helps in better survival and growth of rohu larvae. Therefore, the use of Bacillus circulans as probiotics may be practiced as a tool for formulation of starter diets to obtain better growth and survability of carp larvae.

\section{ACKNOWLEDGEMENTS}

The authors are grateful to the Indian Council of Agricultural Research, New Delhi [Project F. No. 4 (28)/96-ASR-I] and the University Grants Commission (Department of Special Assistance Programme) for financial support to carry on the research work. 


\section{REFERENCES}

Alami-Durante H., N. Charlon, A.M. Escaffre, P. Bergot, 1991: Supplementation of artificial diets for common carp (Cyprinus carpio L.) larvae. Aquaculture, 93: 167-175.

Anonymous, 1983: Formulated feeds for aquaculture in the tropics. Fish feeds and feeding in developing countries - An interim report on the ADCP Feed Development Programme. Aquaculture Development and Coordination Programme. UNDP/FAO, ADCP/REP/83/18: 1-97.

Anonymous, 1985: Standard methods for the examination of water and waste water. $16^{\text {th }}$ edn. American Public Health Association, American Water Works Association and Water Pollution Control Federation, Washington DC.

Bergot P., N. Charlon, H. Durante, 1986: The effect of compound diets feeding on growth and survival of coregonid larvae. Arch. Hydrobiol. Beih. Ergebn. Limnol., 22: 265-272.

Bryant P.L., A.J. Matty, 1981: Adaptation of carp (Cyprinus carpio) larvae to artificial diets. 1. Optimum feeding rate and adaptation age for a commercial diet. Aquaculture, 23: 275-286.

Bulow F.J., 1970: RNA-DNA ratios as indicators of recent growth rates of a fish. J. Fish. Res. Bd Canada, 27: 2343-2349.

Bulow F.J., 1971: Selection of suitable tissues for use in the RNA-DNA ratio technique of assessing recent growth rate of a fish. Iowa St. J. Sci., 46: 71-78.

Bulow F.J., M.E. Zeman, J.R. Winningham, W.F. Hudson, 1981: Seasonal variations in RNADNA ratios and in indicators of feeding, reproduction, energy storage and condition in a population of bluegill, Lepomis macruchirus Rafinesque. J. Fish Biol., 18: 237-244.

Burton K., 1956: A study condition mechanisms of diphenyl amine reaction for the estimation of DNA. J. Biochem., 62: 315.

Charlon N., P. Bergot, 1984: Rearing system for feeding fish larvae on dry diets. Trial with carp (Cyprinus carpio L.) larvae. Aquaculture, 41: 1-9.

Chow K.W., 1980: Microencapsulated egg diets for fish larvae. Fish Feed Technology. Aquaculture Development and Coordination Programme. ADCP/REP/80/11: 355-361.

Csengeri L, M. Petitjean, 1987: Fresh liver powder: a new starter diet for the larvae of a cyprinid fish. Aquaculture, 65: 189-192.

Dabrowslki K.R., S.J. Kaushik, 1985: Rearing of coregonid (Coregonus schinzi pallea Cuv. et Val.) larvae using dry and live food. III. Growth of fish and developmental characteristics related to nutrition. Aquaculture, 48: 123-135.

Das K.M., S.D. Tripathi, 1991: Studies on the digestive enzymes of grass carp, Ctenopharyngodon idella (Val.). Aquaculture, 92: 21-32.

Douillet A., J. Langdon, 1994: Use of a probiotic for the culture of larvae of the Pacific oyster (Crassostrea gigas Thunberg). Aquaculture, 119: 25-40.

Duncan D.B., 1955: Multiple range and multiple $F$-tests. Biometrics, 11: 1-42.

Gatesoupe F.J., 1991: The effect of three strains of lactic bacteria on the production rate of rotifers, Brachionus plicatilis, and their dietary value for larval turbot, Scophthalmus maximus. Aquaculture, 96: 335-342.

Gatesoupe F.J., 1999: Review: The use of probiotics in aquaculture. Aquaculture, 180: 147-165.

Ghosh K., S.K. Sen, A.K. Ray, 2002: Characterization of bacilli isolated from gut of rohu, Labeo rohita, fingerlings and its significance in digestion. J. Appl. Aqua., 12 (3) (In press).

Gildberg A., H. Mikkelsen, E. Sandaker, E. Ringø, 1997: Probiotic effect of lactic acid bacteria in the feed on growth and survival of fry of Atlantic cod (Gadus morhua). Hydrobiologia, 352: 279-285.

Haines T.A., 1973: An evaluation of RNA-DNA ratio as a measure of long-term growth in fish populations. J. Fish. Res. Bd Canada, 30: 195-199.

Haines T.A., 1980: Seasonal patterns of muscle RNA-DNA ratio and growth in black crappie, Pomoxis nigromaculatus. Environ. Biol. Fish., 5: 67-70. 
Helrich K. (ed.), 1990: Official methods of Analysis of AOAC. vol.1, 15 $5^{\text {th }}$ edn. Association of Analytical Chemists Inc., Arlington, VA.

Jancarik A., 1964: Die Verdanung der Hamptnahrstoffe beim Karpfen. St. Fisch. Deren Hilfswiss., 12: 601-684.

Marham R., 1955: Nucleic acids, their components and related compounds. In: Modern methods of plant analysis [Paech K., M.V. Tracey, (Eds.)]. Vol. 4. Springer Varlag, Berlin.

Mitra G.N., I. Das, 1965: On the nutrition of Indian major carp fry. Ind. J. Fish., 12A (1): 1-24.

Mohanty S.N., S.K. Swain, S.D. Tripathi, 1993: Growth and survival of rohu spawn fed on a liver based diet. J. Inland Fish Soc. India, 25 (2): 41-45.

Mohanty S.N., S.K. Swain, S.D. Tripathi, 1996: Rearing of catla (Catla catla Ham.) spawn on formulated diets. J. Aqua. Trop., 11: 253-258.

Munro H.N., A. Fleck, 1966: Recent developments in the measurement of nucleic acids in biological materials. Analyst., 91: 78-88.

Neidhardt F.C., B. Magasanik, 1960: Studies on the role of ribonucleic acid in the growth of bacteria. Biochem. Biophys. Acta, 42: 99-116.

Ringø E., T.H. Birkbeck, 1999: Intestinal microflora of fish larvae and fry. Aquacult. Res., 30, 73-93.

Steffens S.H., 1989: Principles of Fish Nutrition. Ellies Horwood.

Stroband H., K. Dabrowski, 1979: Morphological and physiological aspects of the digestive system and feeding in freshwater fish larvae In: Nutrition des poissons [Fontaine M. (ed.)]. Actes du Colluque CNERNA, Paris.

Strøm E., E. Ringø, 1993: Changes in the bacterial composition of early developing cod, Gadus morhua (L.), larvae following inoculation of Lactobacillus plantarum into the water. In: Physiology and Biochemical Aspects of Fish Development [Walther B.T., H.J. Fyhn (eds.)]. Bergen University, Norway.

Swain S.K., P.V. Rangacharyulu, S. Sarkar, K.M. I)as, 1996: Effect of a probiotic supplement on growth, nutrient utilisation and carcass composition in mrigal fry. J. Aquacult., 4: 29-35.

Tripathi S.D., A.K. Dutta, S. Patra, 1979: High density rearing of rohu spawn in village ponds. Symposium on Inland Aquaculture (Abs.). February 12-14, 1979. CIFRI, Barrackpore.

Trust T.J., R.A.H. Sparrow, 1974: The bacterial flora in the alimentary tract of freshwater salmonid fishes. Can. J. Microbiol., 20: 1219-1228.

Wilder I.B., J.G. Stanley, 1983: RNA-DNA ratio as an index to growth in salmonid fishes in the laboratory and in streams contaminated by carbaryl. J. Fish Biol., 22: 165-172. 
Koushik GHOSH, Sukanta Kumar SEN, Arun Kumar KAY

\section{WZROST I PRZEŻYWALNOŚĆ WYLĘGU GRUBOWARGA, LABEO ROHITA (HAMILTON) ŻYWIONEGO PASZAMI WZBOGACONYMI MIKROFLORĄ JELITOWĄ RYB}

\section{STRESZCZENIE}

Przeprowadzono 21-dniowe doświadczenie dla oceny efektów zastosowania pasz zawierających bakterie jelitowe ryb wytwarzające egzogenne enzymy w żywieniu wylęgu grubowarga, Labeo rohita (Hamilton) (średnia masa $0,3 \mathrm{~g}$ ). Bakterie jelitowe były wcześniej izolowane ze zdrowego narybku grubowarga (średnia masa 3,51 +0,31 g). Przygotowano sześć izokalorycznych $\left(4,24 \mathrm{kcal} \cdot \mathrm{g}^{-1}\right)$, izoazotowych (w przybliżeniu 35\% białka ogólnego) wariantów paszowych (D1-D6) zawierających 32\% mączki rybnej, 34\% wytłoków gorczycy, 30\% otrąb ryżowych, $2 \%$ wątroby dorsza oraz $2 \%$ premiksu witaminowego. Każdy z wariantów paszowych (D1-D6) wzbogacono wcześniej izolowanym szczepem bakterii Bacillus circulans $\mathrm{Lr} 1.1 \mathrm{w}$ ilości odpowiednio: $4 \times 10^{5}, 4 \times 10^{6}, 4 \times 10^{7}, 4 \times 10^{8}$ oraz $4 \times 10^{10}$ komórek na $100 \mathrm{~g}$ paszy. Wylęg żywiony paszą D5 (z dodatkiem $4 \times 10^{8}$ komórek na $100 \mathrm{~g}$ ) uzyskał lepsze przyrosty masy i miał większą przeżywalność $(97,33+1,15 \%)$ w porównaniu do ryb żywionych paszą kontrolną (D1 - bez dodatku bakterii). Zastosowanie paszy D5 spowodowało statystycznie istotnie lepszy dobowy przyrost jednostkowy (SGR). Nieco gorsze okazały się wyniki na paszach D6 i D4. Stosunek RNA i DNA w wylęgu wykorzystano jako wskaźnik wrostu. Współczynnik korelacji $(r)$ na poziomie 0.831 oraz wskaźnik nachylenia prostej regresji (0.79) wskazują na statystycmie istotną korelacje $(\mathrm{p}<0,01)$ pomiędzy proporcjami RNA-DNA oraz dobowym przyrostem jednostkowym.

Received: 15 May 2002

Author's address:

Arun Kumar Ray Prof.

Fisheries Laboratory

Department of Zoology

Visva-Bharati University

Santiniketan - 731 235, West Bengal, India

e-mail: arun_ray1@rediffmail.com 